\title{
Authentic Shakespeare? A Midsummer Night's Dream at Cardiff Castle
}

\author{
by P.B. Roberts
}

For the production: A Midsummer Night's Dream (2019, Lord Chamberlain's Men). Performance attended: 2019-07-06. See production details at the end of the review.

LIKE BINGE DRINKING OR DISAPPOINTING WEATHER, THE LORD CHAMBERLAIN'S MEN'S SHAKESPEARE performances are becoming established as a British summer tradition. Every year their openair productions tour the UK from late spring to early autumn, using early-modern costumes, all-male casts and minimal sets, and incorporating music and dancing of the period. The company pride themselves on the "authenticity" with which they recreate Shakespearean stage conditions. Their slogan declares, "Authenticity-Excellence-Magic," and the site states that they are "built upon the same principles that William Shakespeare himself followed," that audiences will be "enthralled in true Elizabethan fashion" and can "enjoy watching Shakespeare as he first saw it performed." It was possible to enjoy their Midsummer Night's Dream greatly while taking claims of "authenticity" with a pinch of salt.

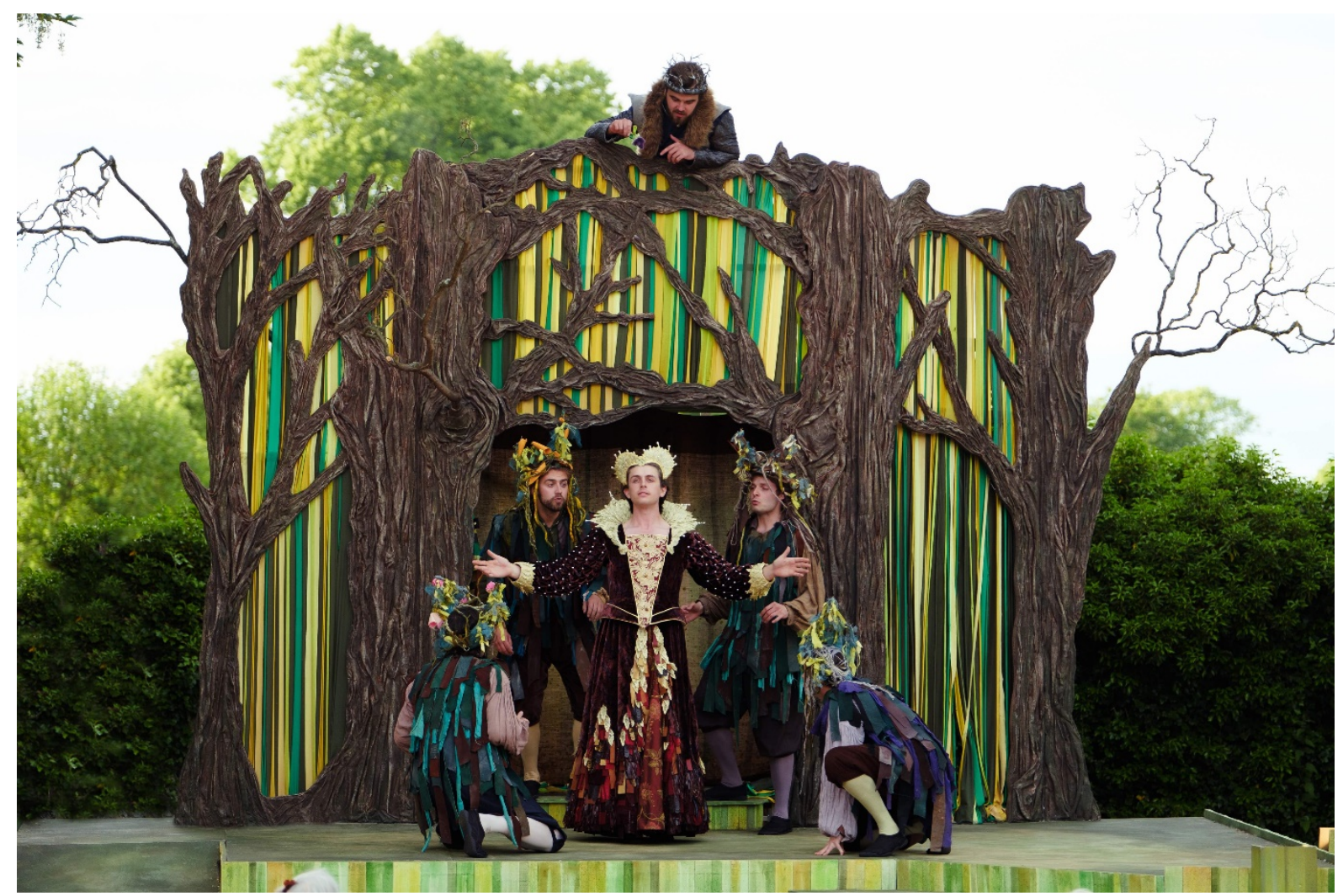

Will de Renzy-Martin as Titania, Maximilian Marston as Oberon, George Readshaw as Peaseblossom, Alex Wilson as Mustardseed, James Camp as Moth, and Joshua Clenister as Cobweb. Photo credit: Jack Offord. 
For one night only, a small stage was erected inside the grounds of Cardiff Castle, and four two-dimensional trees created three arches with their spreading, interlocking boughs. Between the trees hung green-and-yellow fringe curtains. Like symmetrically placed tiringhouse doors, the left and right arches formed entrances and exits; the central arch was a discovery-space that the production would later use as Titania's bower. Seating was unrestricted, and audience-members sat on deckchairs or picnic blankets.

The seven-strong cast assembled onstage and announced the impending performance by singing the madrigal, "Rest sweet nymphs." As usual in LCM productions, all actors were in their twenties (so grown men and not boys or adolescents played the women). Most were dressed identically, with green-and-brown stripes on their jerkins and trunk hose. One actor, conspicuously shorter than the rest, wore a fur hat that came to horn-like peaks on either side. This turned out to be Robin Goodfellow (James Keningale), who commenced the play proper by introducing himself to the audience with a speech transplanted from 2.1: "Over hill, over dale, / Thorough bush, thorough brier." When Robin said, "The king doth keep his revels here tonight; / Take heed the queen come not within his sight," Oberon (Maximilian Marston) appeared soundlessly above on a concealed platform so that the tops of the trees became his balcony. Directed conspiratorially to spectators, with the imperative "Take heed" making them participants in the action, Goodfellow's couplet was reminiscent of traditional British pantomime (those seasonal performances that combine music, crossdressing, dance, and slapstick comedy under the guise of children's entertainment), setting the tone for the rest of the evening.

After this speech, several members of the company sang "Get you home, you merry lads" (a song from the 1628 chapbook

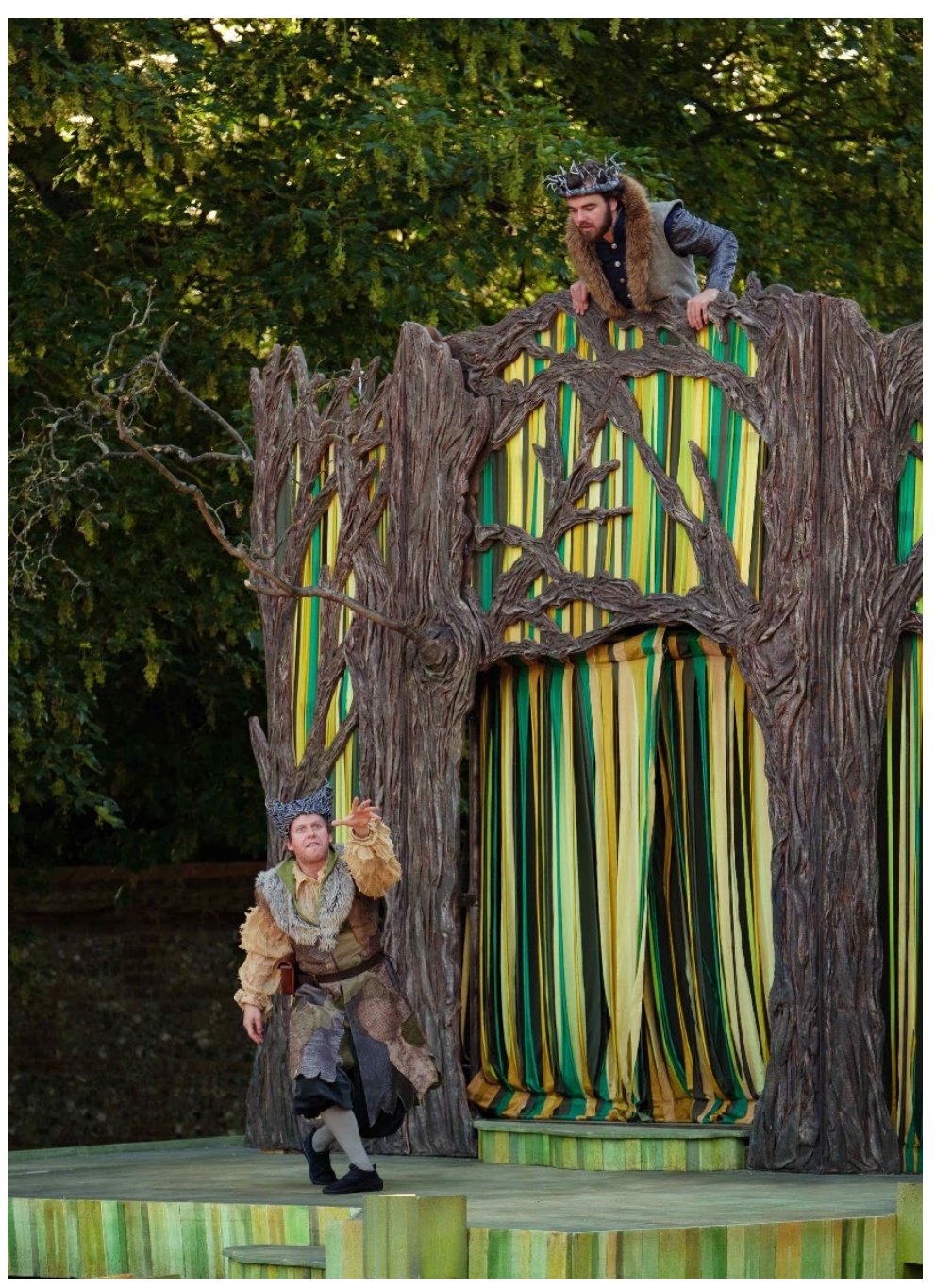

James Keningale as Robin Goodfellow with Maximilian Marston as Oberon. Photo credit: ]ack Offord. 
about Robin Goodfellow, set to music [Sidgwick 96]). Early-modern music would feature throughout the performance. When Quince re-entered in the wood, he was again singing "Get you home, you merry lads." The other Mechanicals joined him, taking different vocal parts, and broke into a jig before the dialogue commenced. The second half began with Keningale reprising the same song to summon all audience members away from the gift shop and the toilets. When Oberon called for music to mark his reunion with Titania, the cast sang Thoinot Arbeau's "Belle qui tiens ma vie" a cappella, and the king and queen danced-an elaborate courtly pavane complete with hand-kissing, which contrasted with the Mechanicals' vigorous rustic dance earlier on. Finally, the cast reprised the Arbeau song as an accompaniment to Robin Goodfellow's and Oberon's final speeches and the epilogue. The actors pavaned around the stage, then exited one by one until only Robin, Oberon, and Titania were left; these three retreated into the bower, then drew the curtain.

There was great charm to these musical moments, but their "authenticity" was debatable. The LCM interpolated song and dance into the performance but deleted it from the text. When Titania (Will de Renzy-Martin) first appeared in her bower, four fairies sang her to sleep, not with "You spotted snakes" but a reprise of "Rest sweet nymphs." Likewise, Theseus interrupted Bottom and Flute before they could start their "Bergomask dance," and in other productions (the 2016 RSC Dream, for instance; see Roberts 2016), this has not been a brief interlude but the climactic, unifying moment of the evening, which all characters joined in, so its omission here was not trivial. Perhaps it's unwise for the Chamberlain's Men to advertise their fidelity to Shakespeare, as this was one of the more textually radical productions of the Dream I've seen. The prologue cut the part of the First Fairy and gave many of their lines to Robin Goodfellow ("Those that 'Hobgoblin' call me, and 'Sweet Puck', / I do their work, and they shall have good luck"); this change meant that the action began not in Athens but in the wood outside. Moreover, Oberon's first entrance happened some time before the Mechanicals' first exit, and he stood onstage watching them, so that their meeting seemed to be happening within his jurisdiction. The boundaries between the human and supernatural worlds were porous from the start.

Many of the textual changes were the result of staging the play with only seven actors. Theseus and Hippolyta's dialogue about the imagination, and whether or not they believe the lovers, moved forward to become an isolated mini scene, apparently so that the actor playing Demetrius, James Camp, could change into Bottom. Snout the tinker (Joshua Glenister) played both Wall and Lion, and when Quince spoke about the actor playing Moonshine ("This man with lantern, dog and bush of thorn"), there was no-one onstage for him to refer to as, because Starveling was cut, Quince played the part himself. The parts of Theseus and Oberon (Maximilian Marston) were doubled, as they so often are (Griffiths 72), but whereas normally the actor rushes off as dawn approaches and performs a rapid costume change, Marston transformed into Theseus onstage. The actor doffed his crown of twigs and fur-lined robe 
while announcing his intent to "Dance in Duke Theseus's house triumphantly," before putting on the Athenian's red sash and striding forward. This was a bravura piece of showmanship palpably enjoyed by the audience.

On their website, the LCM paradoxically seek to present their alterations to the text as further evidence of authenticity:

Touring had been the staple of actors' lives before the creation of permanent theatres. Today it gives The Lord Chamberlain's Men the opportunity to take theatre to all parts of the country, providing access to Shakespeare for communities who might otherwise have little chance to experience his work. [... T] here is evidence that scripts may have been shortened for touring. In this tradition The Lord Chamberlain's Men perform sympathetically edited versions of the text, without losing any of the work's richness and subtlety.

Unfortunately, while there is plenty of evidence that authors expanded plays for court performance or revised old ones for revival, the theory that actors cut texts for "provincial" touring has taken something of a pounding since A.W. Pollard's time (Dutton 97-168). Recent scholars such as Paul Werstine have shown it to rest on assumptions about "provinces" by twentieth-century metropolitans, rather than hard fact. In a panoramic survey of earlymodern play-quartos, Laurie E. Maguire finds only spectral evidence that one, The Merry Devil of Edmonton (1608), may have been trimmed for a venue with fewer resources (Maguire 282283, 329-332). In the absence of further proof of how London actors operated, in London or in the despised provinces, the printed text is our best means of reconstructing performances, and all productions, adapting the text to fit their exigencies, are as authentic as each other, codpieces notwithstanding.

Overall, A Midsummer Night's Dream is a better fit for the Chamberlain's Men than The Tempest, their text last year. As I argued in my review of the LCM Tempest, (Roberts 2019), enchantment alternates with autumnal melancholy in The Tempest, and the LCM house style, with its emphasis on horseplay, jars with both of these moods. (Of the fifteen productions they have staged since their formation in 2004, eleven have been comedies.) Perhaps the gossamer clowning of A Midsummer Night's Dream (here very much emphasized) suits them better. Characters so often seem driven by spontaneity: Helena decides to betray her friend's confidence on a whim; Puck, temporarily neglecting his orders from Oberon, decides to play a trick on Bottom and friends on a whim; and Theseus overrules Egeus (and Athenian law) more or less on a whim. So, even without the influence of "love-in-idleness," all characters seem capable of behaving irrationally. In this pared-down production, where plenty of speaking parts were cut (Snug, Starveling, the First Fairy), the much-discussed but dialoguefree "Indian Boy" did not appear, as over the centuries he has (Griffiths 30, 126), and when he is unseen, his importance in Titania and Oberon's wrangling seems more of a contrivance. 
Similarly, Lysander and Demetrius were almost identical (with no difference in their clothing, demeanours, or accents), so that Egeus's preference for Demetrius over Lysander, and Hermia's opposition to this, seemed entirely arbitrary, a Plautine device to get the four lovers out of Athens and into the forest. Especially with the broad acting style adopted, the characters became eloquent marionettes, jerked around by a farcical plot. Titania's speech about the chaos in the elements resulting from her quarrel with Oberon (well and sombrely delivered by de Renzy-Martin) was a rare moment of sobriety; the king looked up to the sky with uncharacteristic awe and reverence at her mention of "the moon, the governess of floods," as if the play's master manipulator felt momentarily dwarfed by a force greater than himself.

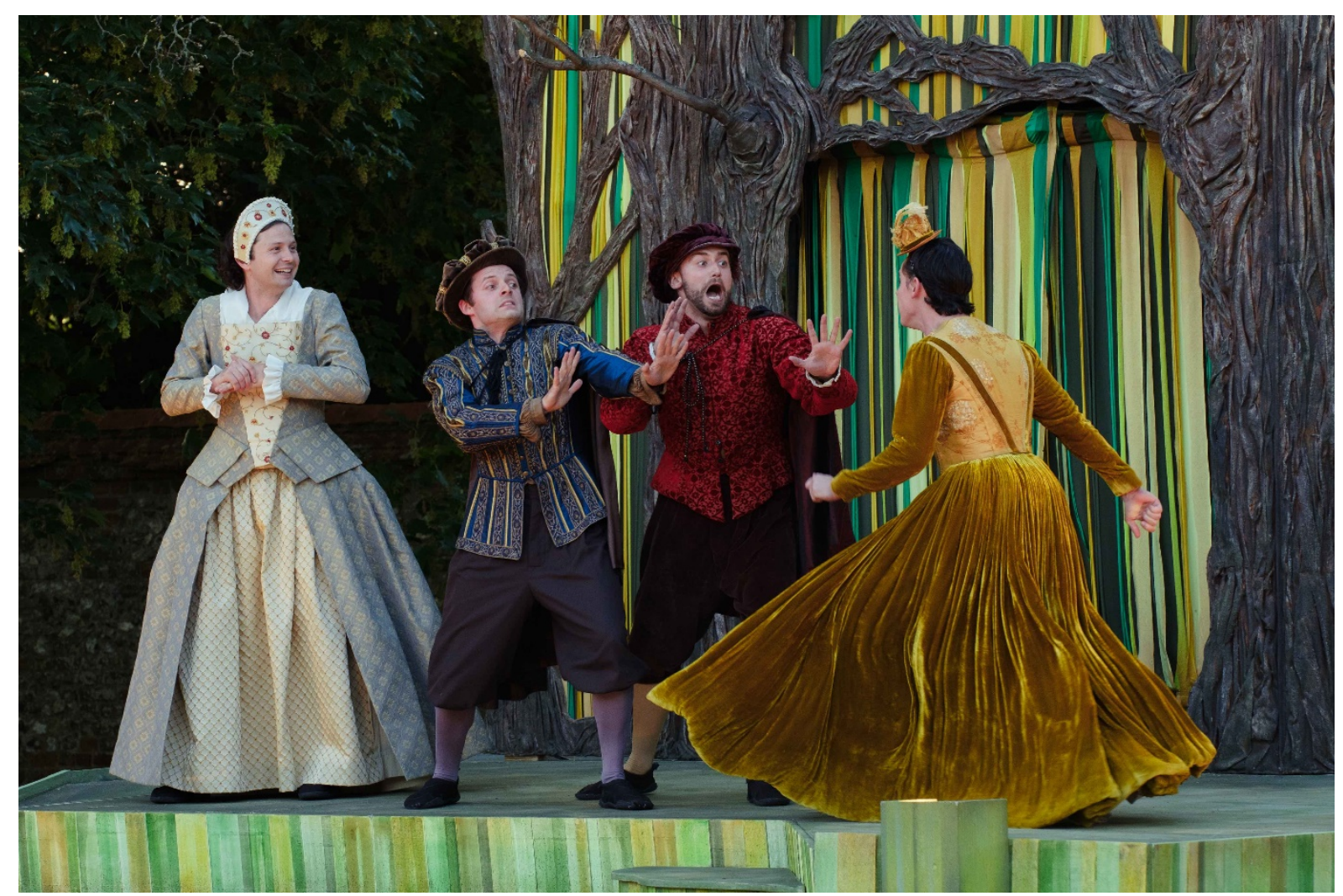

George Readshaw as Helena, James Camp as Demetrius, Alex Wilson as Lysander, and Joshua Glenister as Hermia. Photo credit: Jack Offord.

The Pyramus and Thisbe scene is a hurdle that not all productions clear. I have always found the invitation to laugh at working men humiliating themselves in front of aristocracy far more genuinely discomfiting than any of the play's nocturnal transformations. In a variety of ways, the LCM diminished the awkwardness of the "hard-handed men" embarrassing themselves before the ducal couple. Because of textual cuts and doubling, Theseus and his bride were the only onstage audience, and their interruptions were kept to a minimum. There was no difference in accent between Quince, Bottom, and the elite characters; whatever his ostensible job title, Peter Quince seemed to be an Elizabethan white-collar worker. Additionally, this production's Quince was something of a pedant, interrupting Bottom to 
correct his pronunciation of "Phibbus" (foreshadowing his later corrections of Bottom at the Mechanicals' rehearsal in the wood). Neither was there anything remotely "common" about the weaver himself. Instead, he was a strangely affected and fastidious labourer. The actor, James Camp, spoke very distinctive body-language in the part, walking with elbows bent and hands permanently up, wrists back, so that even with a full-sized ass's head on, Bottom was instantly recognizable. (Squeamish about physical contact, he was very much a "tender ass," shrieking in horror on seeing Titania, and again when the grieving Thisbe touched him. When Titania said she would "purge thy mortal grossness," he reflexively covered his genitals.)

As a consequence of all of these performance choices, there was less class-related frisson to the play-within-the-play and its reception at court. Its major drawback was a lack of rehearsal. Wall, for instance, unsure where exactly he was supposed to be, forgot it was his job to part the lovers and stood at the back of the stage, smiling inanely. Snout as the Lion forgot to leave Thisbe's mantle behind for Pyramus to find, so he had to re-enter. Bottom as Pyramus wore an antique plumed helmet and a breastplate and, at the crucial moment, recognized too late that the breastplate meant he couldn't stab himself. Flute, meanwhile, was clearly still unhappy at playing a woman by the time of the performance, and delivered his lines tonelessly, with no enthusiasm.

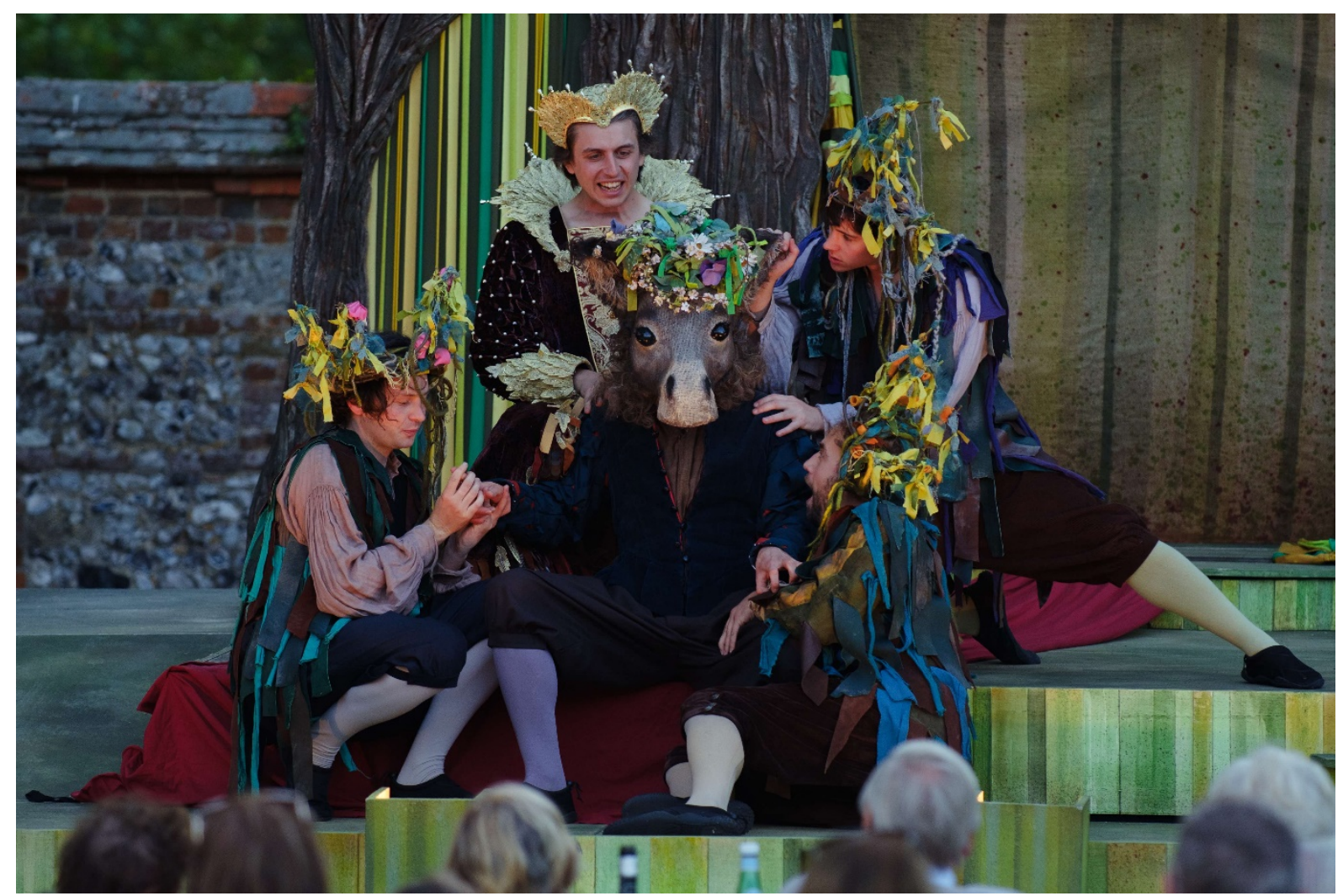

James Camp as Bottom, Will de Renzy-Martin as Titania, George Readshaw as Peaseblossom, and Alex Wilson as Mustardseed. Photo credit: Jack Offord.

Like the aforementioned pantomimes (a nineteenth- and not sixteenth-century tradition), past LCM productions have seemed to find the sight of men in women's clothes inherently 
hilarious, inviting the audience to be amused by something an Elizabethan might well have taken entirely in their stride and bringing with them a disconcerting whiff of homophobia (Roberts 2019). On this occasion, however, the female characters were played almost naturalistically, as women and not drag queens. Indeed, this production seemed almost eager to introduce the homoerotic. With their shaggy costumes and habit of throwing both their arms violently up into the air by way of salute, Titania's retinue were rough, sylvan, and visibly male (Alex Wilson's Mustardseed had a full beard), and they proved to be just as enamoured with Bottom as their mistress was. On her command, the fairies grabbed Bottom and started caressing him; the "courtesies" they were going to do him seemed to be sexual. Camp heehawed in consternation as they dragged him to Titania's bower. When he reappeared, however, Bottom, who plainly considered himself the star performer of Peter Quince's troupe, had come to enjoy being the centre of the fairies' attention (and the object of their very tactile ministrations), and basked in the glow of amorous appreciation as the queen and her courtiers fondled him simultaneously. This was the Chamberlain's Men doing what all productions have done, filling in the blank spaces in Shakespeare in a way that reflects their historical moment. Were these sexualized fairies authentically Elizabethan, since Robin Goodfellow parades a tumescent penis on the title-page of the chapbook the Men took one of their songs from, and since other stage-fairies of the era had an erotic element to their mischief (Kott 313-314)? Like the rest of the audience, I was enjoying myself too much to care.

\section{References}

Dutton, Richard. Shakespeare, Court Dramatist. Oxford UP, 2016.

Griffiths, Trevor R., ed. Shakespeare in Production: A Midsummer Night's Dream. Cambridge UP, 1996.

Kott, Jan. "Bottom and the Boys." New Theatre Quarterly 36 (1993): 307-315.

Maguire, Laurie E. Shakespearean Suspect Texts: The "Bad" Quartos and their Contexts. Cambridge UP, 1996.

Roberts, P.B. (Roberts 2017.) “A Midsummer Night's Dream, presented by the Royal Shakespeare Company and Everyman Theatre at the New Theatre, Cardiff, 28 May 2016." Early Modern Literary Studies 19.2 (2017). URL:

https://extra.shu.ac.uk/emls/journal/index.php/emls/article/view/340. 
Roberts, P.B. (Roberts 2019.) “The Tempest, presented by the Lord Chamberlain's Men at

Cardiff Castle, 7 July 2018." Early Modern Literary Studies 21 (2019). URL:

https://extra.shu.ac.uk/emls/journal/index.php/emls/article/view/493/355.

Robin Good-fellovv, His Mad Prankes, and Merry Iestes. 1628, London. STC 12016.

Sidgwick, Frank, ed. The Sources and Analogues of "A Midsummer-Night's Dream." Chatto \& Windus, 1908.

Werstine, Paul. "Touring and the Construction of Shakespeare Textual Criticism." Textual Formations and Reformations. Ed. Laurie E. Maguire and Thomas L. Berger. University of Delaware Press; Associated University Presses, 1998, pp. 45-66.

\section{Links}

Lord Chamberlain's Men. www.tlcm.co.uk.

[F]ifteen productions. http://www.tlcm.co.uk/past-productions/.

Midsummer Night's Dream. https://youtu.be/6tGJywsJVjs (a recording of the 2019 LCM production).

The Tempest. https://youtu.be/KAsRwFyRIps (a recording of the 2018 LCM production). 


\section{Production Details}

\section{General}

Title

A Midsummer Night's Dream

Year

2019

Theatre Company

The Lord Chamberlain's Men

Theatre

Cardiff Castle

Start Date

2019-05-23

End Date

2019-09-15

\section{Cast}

\begin{tabular}{|c|c|}
\hline Theseus / OBERON & MAXIMILIAN MARSTON \\
\hline HipPolyta / Titania & WILL DE RENZY-MARTIN \\
\hline Egeus / Philostrate / Robin GoOdFELlow & JAMES KENINGALE \\
\hline HERMIA / COBWEB / TOM SNOUT & JOSHUA GLENISTER \\
\hline Lysander / Mustardseed / Peter Quince & ALEX WILSON \\
\hline DEMETRIUS / MOTH / NICK BOTTOM & JAMES CAMP \\
\hline Helena / Peaseblossom / Francis Flute & GEORGE READSHAW \\
\hline
\end{tabular}

\section{Creatives}

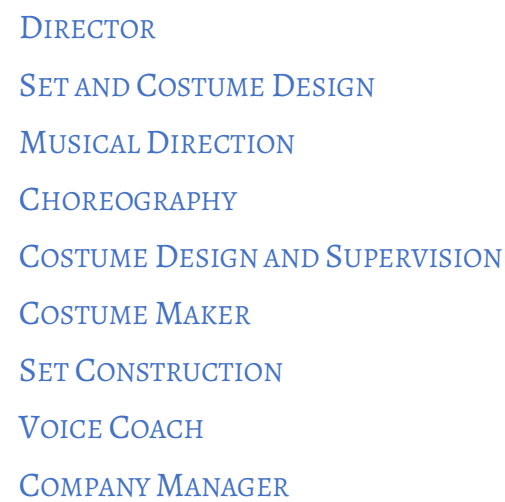

Peter STICKNEY

MORGAN BRIND

ALEX BEETSCHEN

DARREN ROYSTON

POLLY LAURENCE

Planet Costume Services

SPLINTER SCENERY

JACQUIE CRAGO

AARON BARKER 